\title{
A Numerical Study on the Effect of Engine Characteristics by Using Ethanol-moringa-diesel Fuel
}

\author{
Tikendra Nath Verma*, Prem Kumar Chaurasiya**, Upendra Rajak***, Krishnakant Dhakar ****, Leeladhar \\ Nagdeve***** \\ *Department of Mechanical Engineering, Maulana Azad National Institute of Technology, Bhopal, India \\ **Department of Mechanical Engineering, Sagar Institute of Science and Technology, Bhopal, India \\ ***Department of Mechanical Engineering, Rajeev Gandhi Memorial College of Engineering and Technology, Nandayal, India \\ ****Department of Industrial and Production Engineering, Shri G.S. Institute of Technology and Science, Indore, India \\ *****Department of Mechanical Engineering, National Institute of Technology, Delhi, India. \\ Corresponding Author: pre.chaurasiyaa@gmail.com
}

\begin{abstract}
Environmental contamination has been increasing day by day due to increase in use of fossil fuel, therefore world is moving towards unconventional sources of energy generation. In this study, a diesel engine characteristic was analysed in a single cylinder, four strokes, water cooled, direction injection (DI) diesel engine by using two different fuel blends, one is non-edible oil (Moringa oleifera) and another one is alcohol (Ethanol) and operating at different engine load. Diesel engine characteristics were examined in terms of engine performance, emission and combustion characteristics by using Diesel-RK software and before that validate the numerical result with experimental result. The result shows that MB20 has reduction of 2.26\%, 7.37\%, 2.6\%, 8.3\% and $15.02 \%$ in BTE, EGT, Smoke emission, MRPR and NOX respectively and increases $8.9 \%$ and $12.34 \%$ in SFC and CO2 emission. The MBE20 has increased by $2.9 \%$ and $18.75 \%$ in SFC and $\mathrm{CO} 2$ emissions and decrease of $1.25 \%, 2.45,5.44 \%$, and $3.06 \%$ in BTE, EGT, MRPR and NOX respectively was found as compare to diesel fuel. In this paper, mixing various blends $20 \%$ of Moringa Oleifera biodiesel fuel with $20 \%$ of ethanol gives optimum blends ratio.
\end{abstract}

Keywords: Combustion; Diesel engine; Emission; Ethanol; Moringa oleifera; Performance analysis.

\section{INTRODUCTION}

The progress of nation depends on how much the nation is technologically fit. Maxi- mum energy fulfilled from fossil fuel like petroleum, natural gas and coal. In the field of automotive and agriculture industries diesel engine is widely used. Generally, it will transform chemical energy into mechanical energy $[1,2]$. In diesel engine NOX and $\mathrm{PM}$ emission is a serious problem, and this will be a challenging task to reduce the emission [3]. Sulphur is the main constituent of acid rain and its presence in diesel cause fatal effect on environment as well as humans and other species [4]. The use of biofuel also includes many reasons such as environ- mental concern like climate change and depletion on fossil fuel. Due to good mixing characteristics of air and wide flammability limit and self-ignition temperature gaseous fuels are considered to be good for internal combustion engines. These properties enable it to operate with lean mixtures or higher compression ratio hence improving thermal efficiency and reducing emission like $\mathrm{HC}, \mathrm{CO} 2, \mathrm{NOX}, \mathrm{SOX}$ and particulate matter etc. These include natural gas, hydrogen, biogas, and other fuel constituted gaseous fuel are used in internal combustion engines [5]. Mofijur et al. [6] evaluated properties of Moringa biodiesel fuel at different speed at full load condition, and blends are 10\% (B10) and 20\% (B20) by volume and com- pare to diesel fuel. They have found that average reduction of brake power and BSFC is more as compared to diesel fuel. Blend fuel reduces hydrocarbon and carbon monooxide but increases nitric oxide slightly. M.M. Rashid et al. [7] checked the performance and emission characteristic of 20\% Moringa oleifera biodiesel and compared the results of 20\% Palm, 20\% Jatropha biodiesel and 100\% diesel. Here, Palm biodiesel has better result as compare to Moringa and Jatropha blend. This paper shows that brake power is lower at (6.92 to 8.75\%) and BSFC is higher at 
(5.42 to 8.39\%) as compare to diesel fuel. U. Rajak et al. [8] described the paper numerically by using Diesel RK software and shows 9 different biodiesel characteristics after that result were compared with diesel fuel. Result shows less ignition delay as compared to diesel fuel, smoke and PM value decreases in biodiesel and with an increase in engine load SFC decreases. Kamel Bencheikh et al. [9] this article shows that the characteristics and performance of ternary biodiesel-diesel-propanol, biodiesel blend made from waste cooking oil. Result improved the BSEC, BSFC, and reduces exhaust gas temperature, smoke, $\mathrm{CO}$ etc. and also propanol has been added in diesel to improve cold flow properties, density, kinematic viscosity, and to maintain cetane number and high heating value. Datta A et al. [10] mixed alcohol (ethanol, methanol) in diesel fuel, and checked the performance and emissions by Diesel RK software and validate the experimentally. Result shows that higher brake thermal efficiency, higher specific fuel consumption and also reduction of NOX emissions. If separate use of ethanol 15\% and methanol 15\% are used in this paper and mix with palm oil then result shows that decrease in NOX emissions by $30 \%$ and $19 \%$ respectively. Alcohol blended biodiesel has peak pressure rise is lower. In this paper ethanol is mixed in diesel and moringa biodiesel by an amount of 20\%. The blend fuel MBE20 (80\% biodiesel- diesel and 20\% Ethanol) are tested on single cylinder, four stroke, $17.5 \mathrm{CR}, 1500 \mathrm{rpm}, 23.5$ injection timing and variable engine loading condition $(25 \%, 50 \%, 75 \%$, $100 \%$ ) by diesel RK software. The engine behavior was studied for performance, combustion, emission parameter.

\section{MATERIAL AND METHOD}

As In the present research work, properties of moringa biodiesel fuel and its blends were taken from the previous published research article and it is shown in Table 1. In this investigation, diesel RK software is used to evaluate the effect of different biodiesel blends, analyse their engine behaviour in based on performance, emission and combustion by mixing $20 \%$ of moringa oleifera with $20 \%$ ethanol. Table 2 shows the specification of engine that is single cylinder four stroke, water cooled, Engine speed 1500rpm, injection timing $23.5^{\circ} \mathrm{bTDC}$, compression ratio 17.5 and loading condition varies at $25 \%, 50 \%, 75 \%$ and $100 \%$ during simulation.

Table 1. Physio-chemical chattels of biodiesel, diesel ethanol and moringa [11], [8] \& [13]

\begin{tabular}{|l|l|l|l|l|l|l|l|c|}
\hline Properties & $\begin{array}{l}\text { Density } \\
(\mathrm{kg} / \mathrm{m3})\end{array}$ & $\begin{array}{l}\text { Viscosity } \\
(\mathrm{mm} 2 / \mathrm{s})\end{array}$ & $\begin{array}{l}\text { Calorific } \\
\text { Value } \\
(\mathrm{MJ} / \mathrm{kg})\end{array}$ & $\begin{array}{l}\text { Flash } \\
\text { point } \\
\left({ }^{\circ} \mathrm{C}\right)\end{array}$ & $\begin{array}{l}\mathrm{C} \\
(\% \text { wt. })\end{array}$ & $\begin{array}{l}\text { H } \\
(\% \text { wt. })\end{array}$ & $\begin{array}{l}\text { O } \\
(\% \text { wt. })\end{array}$ & $\begin{array}{l}\text { Cetane } \\
\text { number }\end{array}$ \\
\hline Diesel (B0) & $829-850$ & $2.87-3.63$ & $41-45.36$ & $56-76$ & 86.1 & 13.8 & 0.1 & $52.4-59$ \\
\hline $\begin{array}{l}\text { Moringa } \\
\text { oleif- era } \\
\text { biodiesel } \\
(\text { MB100 })\end{array}$ & $859-866$ & $4.03-5.05$ & $39-40.6$ & $162-189$ & 76.7 & 12.5 & 10.8 & $54-56$ \\
\hline $\begin{array}{l}\text { Ethanol } \\
(\text { E100 })\end{array}$ & 789 & 1.15 & $27-32$ & 12 & 52.2 & 13 & 34.8 & $5-7$ \\
\hline
\end{tabular}


Table 2. Specification of Test Engine

\begin{tabular}{|l|l|}
\hline Parameters & Specification \\
\hline Engine & Single cylinder, four strokes \\
\hline Fuel injection & Direct injection \\
\hline Compression ratio & $17.5: 1$ \\
\hline Cooling & Water cooled \\
\hline Load & $25 \%, 50 \%, 75 \%, 100 \%$ \\
\hline Bore diameter & $80 \mathrm{~mm}$ \\
\hline Connecting rod length & $235 \mathrm{~mm}$ \\
\hline Dynamometer & Eddy current type \\
\hline Injection timing & $23.5^{\circ} \mathrm{bTDC}$ \\
\hline Rated power & $3.5 \mathrm{~kW}$ \\
\hline Orientation & Vertical \\
\hline
\end{tabular}

\section{UNCERTAINITY ANALYSIS}

To retain accuracy of experiment uncertainty analysis must be performed. Instrument selection, calibration, environment, observation and operating conditions etc causes error in experiment. Linearized approximation method of uncertainty was used to determine (BSFC) brake-specific fuel consumption [6]. Percentage uncertainties of the device used in the experimentation was source for calculation of the percentage uncertainties of a variety of factor such as brake power, brake specific fuel consumption (BSFC), brake specific energy consumption (BSEC) and brake thermal efficiency (BTE) [12]. Total uncertainties are 1.56\%. Table 3 shows the uncertainties of all measurement.

Table 3. Uncertainties in Engine

\begin{tabular}{|l|l|c|c|}
\hline Instruments & $\begin{array}{l}\text { Abrasion of } \\
\text { instruments }\end{array}$ & Type & Uncertainty (\%) \\
\hline Temperature & TS & K & \pm 0.1 \\
\hline Sensor & & & \pm 0.15 \\
\hline Pressure sensor & PS & Kistler & \pm 0.1 \\
\hline Speed sensor & SS & - & \pm 0.5 \\
\hline Crank angle & CAE & - & \pm 0.2 \\
\hline Encoder & & - & \pm 1 \\
\hline Load cell & LC & - & \pm 1 \\
\hline Burette for fuel & BFM & & \\
\hline measurement & & AVL437 & \\
\hline Smoke & S & AVL Di & \\
\hline Exhaust gas & & Gas 444 & \\
\hline Analyser & & - & \pm 0.15 \\
\hline CO2 & - & - & \\
\hline O2 & - & & \\
\hline
\end{tabular}




\section{DIESEL RK TOOL VALIDATION}

Conservation of mass

Rate of change mass across the boundary of the system are given in below equation

$$
\frac{\mathrm{dm}}{\mathrm{dt}}=\sum_{\mathrm{i}} \mathrm{m}_{\mathrm{i}}
$$

Species conservation

The estimation of species has been given on the basis of mass fraction in equation.

$$
\mathrm{Y}_{\mathrm{i}}=\frac{\mathrm{m}_{\mathrm{i}}}{\mathrm{m}}
$$

Conservation of energy

For an open thermodynamic system, a general energy equation can be given as

Fuel consumption

$$
\frac{\mathrm{d}(\mathrm{mu})}{\mathrm{dt}}=-\mathrm{P} \frac{\mathrm{dv}}{\mathrm{dt}}+\frac{\mathrm{dQ} \mathrm{ht}}{\mathrm{dt}}+\sum_{\mathrm{i}} \mathrm{m}_{\mathrm{i}} \mathrm{h}_{\mathrm{i}}
$$

BSFC of an engine is defined as fuel consumption per unit time per brake power. And mathematically given in equation

$$
\mathrm{SFC}=\frac{\mathrm{m}_{\mathrm{f}}}{\mathrm{P}_{\mathrm{b}}}
$$

For evaluating brake mean efficiency pressure and brake power it is important to perform modelling of engine friction and losses associated with it. McAulay et al. [13] recommended that there is linear deviation of entire loss in solitary cylinder compression ignition engine among peak pressure in the interior of cylinder as well with piston speed. Diesel RK software gives all loses in conditions of frictional mean effective pressure

$$
\mathrm{FMEP}=\alpha+\beta \mathrm{P} \_\mathrm{max}+\gamma \mathrm{S} \_\mathrm{p}
$$

Where $\alpha, \beta, \gamma$ are constant that are depends on engine geometry.

Heat release process is described in diesel RK software with help of multizone combustion model. Heat release rate is in four process i.e. delay period, controlled combustion period, premixed combustion period, and burning period model. Physical and chemical features of all four process are distinct but HRR is affected.

\section{SIMULATION VALIDATION}

The experimental result was accomplished on four strike diesel engines with single cylinder at the throttle valve fully open. The setup helps us to study the in-cylinder pressure, heat release rate at constant injection timing (23.5区 bTDC), constant speed $1500 \mathrm{rpm}$ and CR 17.5 with diesel fuel using diesel-RK tool for validation. Fig.1 (cylinder pressure) Fig.2 (heat release rate) is shows that result from experiment and from numerical has better concurrence. Due to variation in condition between the experiment and simulation theory, error deviation is observed in table 4. An error deviation of $1.68 \%$ was found for in-cylinder pressure and for $2.6 \%$ heat release rate with crank in this study, which can be clearly seen from graph (Figure $1 \& 2$ ). 
Table 4. Experimental and numerical results at full load condition for tool validation

\begin{tabular}{|c|c|c|c|}
\hline Parameter & Experimental & Simulation & Error Deviation \\
\hline Cylinder pressure (bar) & 85.578 & 87.047 & $1.68 \%$ \\
\hline HRR (J/deg) & 84.1 & 81.967 & $2.6 \%$ \\
\hline
\end{tabular}

\section{RESULT AND DISCUSSION PERFORMANCE CHARACTERISTICS}

\section{Specific Fuel Consumption}

SFC of an engine is defined as fuel consumption per unit time per power. SFC and thermal efficiency are inversely proportional. Figure 3 shows variation of SFC at different load for different blends with diesel and diesel fuel. Biodiesel blends has more specific fuel consumption than diesel because of increase of amount of density, viscosity and injected fuel are increases $[16,17]$. Result shows that with an increase in loading condition SFC decreases. The SFC was found to be more of MB20 than B0. The SFC for diesel B0, MB20, MBE20 at CR 17.5 and engine speed $1500 \mathrm{rpm}$ are found to be $248.19,270.39$, and 255.48 respectively at $100 \%$ load. Blend MBE20 at engine speed of $1500 \mathrm{rpm}$ and $17.5 \mathrm{CR}$ which is $2.9 \%$ more as compare to diesel fuel (B0) gives better performance.

\section{Brake Thermal Efficiency (BTE)}

Figure 4 shows that on increasing loading condition BTE increases. Biodiesel have lower BTE as compare to diesel because higher viscosity and lower density and less amount of oxygen and this will affects fuel atomization $[18,19]$. It was observed from the simulation that the BTE for B0 ranges from $21.342 \%$ to $34.508 \%$ and for MBE20 ranges from 20.489 to $34.074 \%$ at $25 \%$ and $100 \%$ loading respectively. Blend MBE20 at engine speed of $1500 \mathrm{rpm}$ and $17.5 \mathrm{CR}$ which is $1.25 \%$ lesser as compare to diesel fuel (B0) gives better performance.

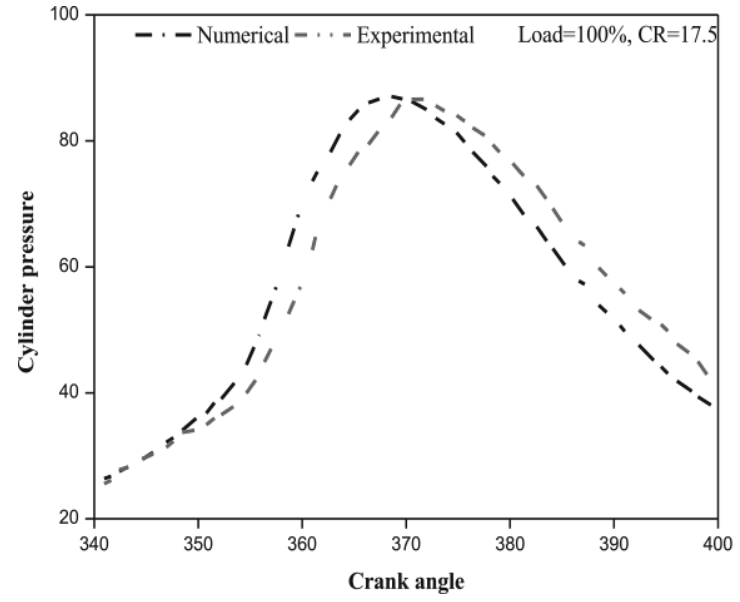

Figure 1. Validation of CP versus crank angle

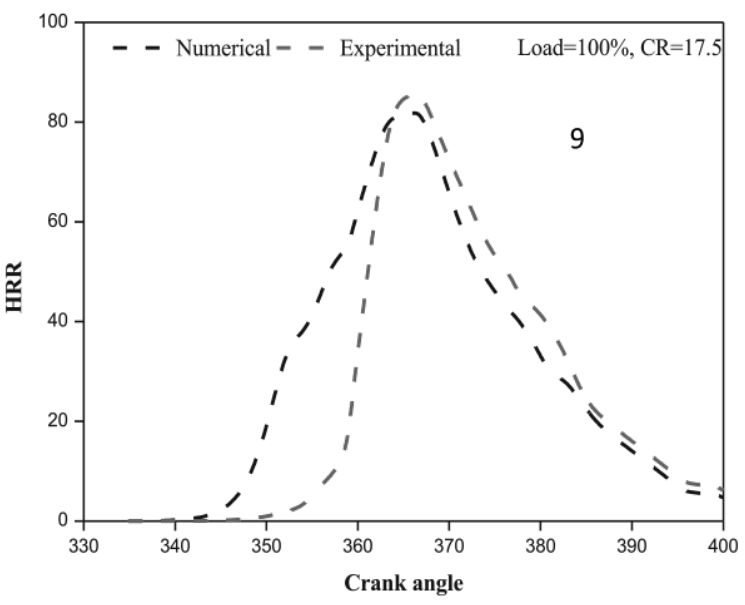

Figure 2. Validation of HRR versus crank angle 


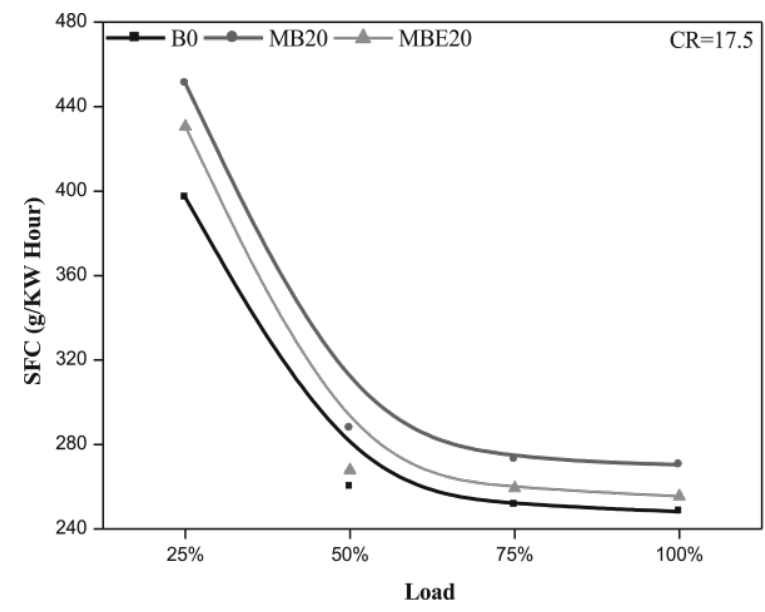

Figure 3.Variation of SFC with engine load

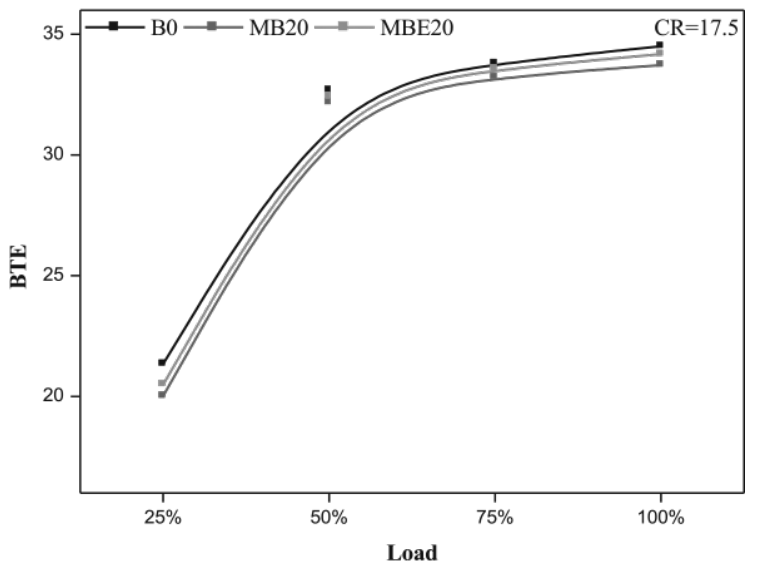

Figure 4. Variation of BTE with engine load

\section{Exhaust Gas Temperature}

EGT imitates the quality of combustion in engine cylinder. Quantity of oxygen in fuel has higher effect on EGT. To determine exhaust gas temperature ignition delay is important parameter. The longer the ignition delay longer is the combustion that results the higher EGT [20]. Figure 5 shows deviation of EGT with altered blends at various engine loads. Biodiesel and its blends having lesser EGT values for all load condition than diesel fuel, this is because of complete combustion of biodiesel fuel. EGT for B0, MB20, and MBE20 at CR 17.5 was found to be 760.87, 705.07 and 742.6. It is observed from the result that value of EGT of MBE20 and B0 are very near. The EGT was found to be reduced by $7.3 \%$ in MB20 and in $2.4 \%$ MBE20 as compared to B0.

\section{COMBUSTION CHARACTERISTICS}

\section{Cylinder Pressure}

Cylinder pressure is lower in biodiesel blends from those of diesel fuel because of small calorific value and higher viscosity. The change of cylinder pressure and certain crank angle at different loading condition are given in figure 6. The cylinder pressure of diesel fuel is higher than the biodiesel blend at $1500 \mathrm{rpm}$ and $17.5 \mathrm{CR}$. At $363^{\circ} \mathrm{CA}$ cylinder pressure was found to be 85.3,81.9,84.3bar for B0, MB20 and MBE20 respectively. Cylinder pressure has lowered by $1.17 \%$ at B0 in MBE20.

\section{Ignition Pelay}

The changes in ignition delay with different loading condition $(25 \%, 50 \%, 75 \%$, and $100 \%)$ at 17.5 are shown in figure 7. It indicates that when load increases ignition delay decreases because of maximum heat generated before the cycle. Diesel fuel (B0) has maximum ignition delay as compare to biodiesel blends because in diesel fuel oxygen is more. The ignition delay for diesel fuel (B0) is 16.245, 15.282, 14.606, 14.105 at 25\%, 50\%, 75\%, $100 \%$ respectively. Blends MB20 shows $14.326,13.428,12.852,12.421$ at $25 \%, 50 \%, 75 \%, 100 \%$ respectively and the optimum result is MBE20 that are $14.879,13.973,13.353,13.065$ at $25 \%, 50 \%, 75 \%, 100 \%$ respectively. Optimum result MBE20 was decreased by $7.37 \%$ as compare to diesel fuel at $100 \%$ loading condition. 


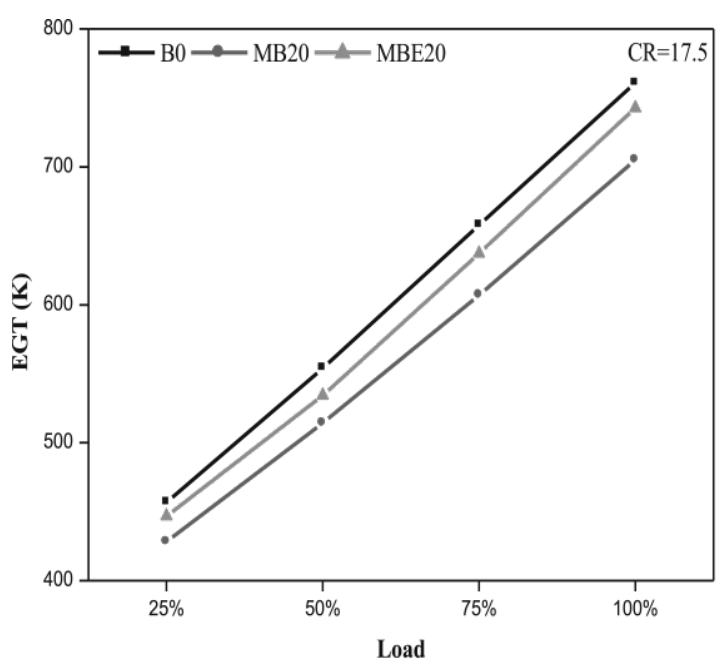

Figure 5. Deviation of EGT with engine load

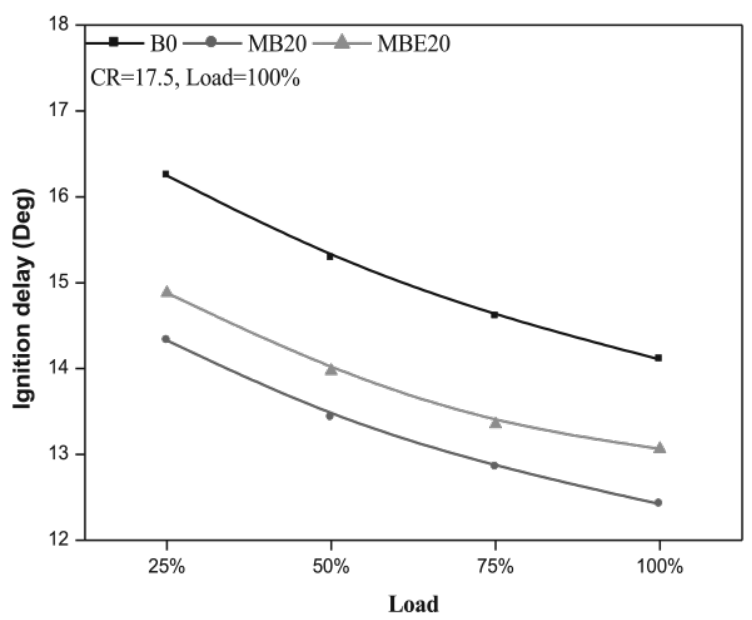

Figure 7. Variation of ignition delay with load

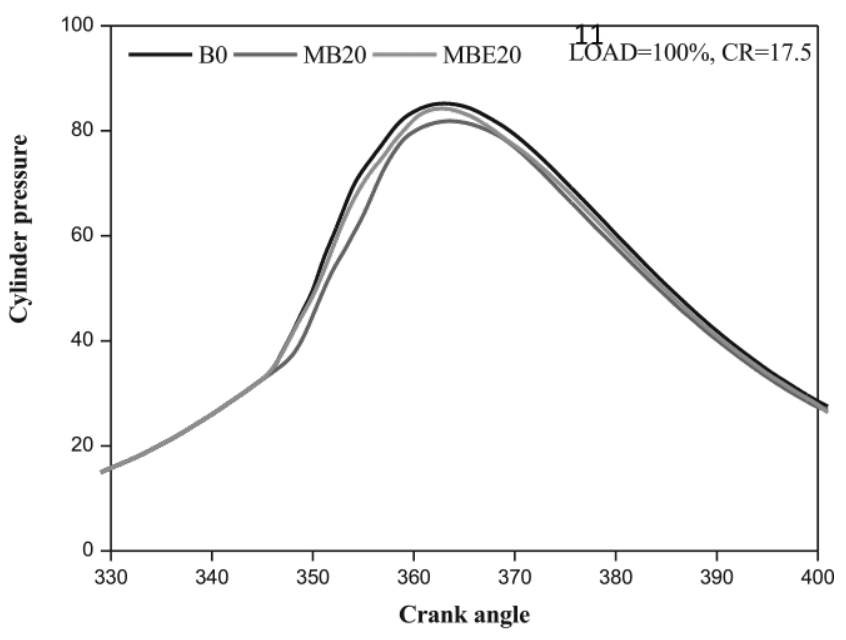

Figure 6. Deviation of cylinder pressure with crank angle

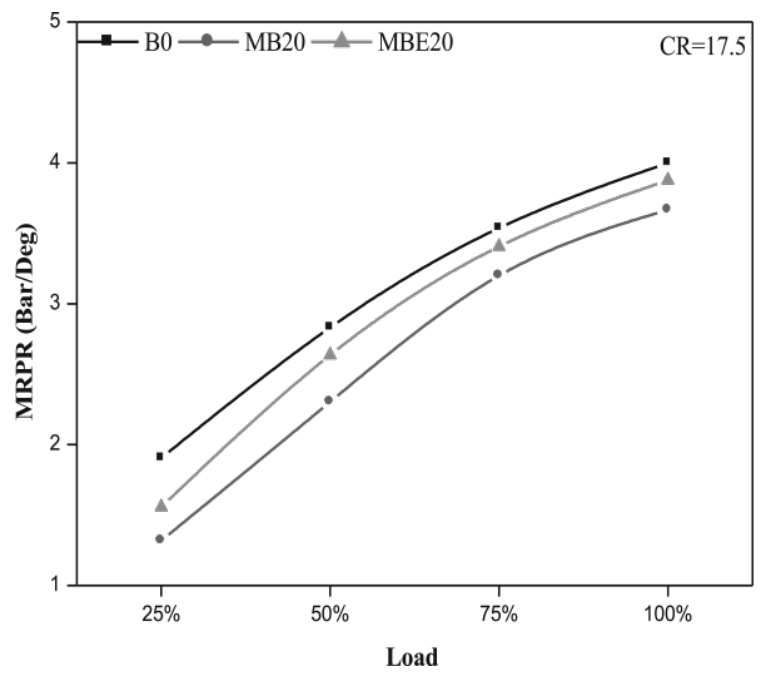

Figure 8. Variation of MRPR with load

\section{Maximum Rate of Pressure Rise}

Figure 8 shows the deviation of load against MRPR. At different load condition, the MRPR is increases when loading condition increases. It encourages an unwanted occurrence known as knocking [21]. Result was found to be about $14.105,12.421$, and 13.065 for B0, MB20 and MBE20 respectively at CR 17.5 with full loading condition. The MRPR was found to be $7.3 \%$ higher for B0 than MBE20 at CR17.5. 


\section{EMISSION CHARACTERISTICS}

\section{CO2 emission}

Figure 9 shows altered engine loads for a mixture of tested fuel blends. Blended fuels have higher emissions as compared to pure diesel. For all loading condition, the CO2 emission of MB20 and MBE20 was found to be more than the B0. At $1500 \mathrm{rpm}, 17.5 \mathrm{CR}$ and full loading condition the $\mathrm{CO} 2$ emission was observed to be $797.89,896.41,947.54 \mathrm{~g} / \mathrm{Kw}$ hour for B0, MB20 and MBE20 respectively.

\section{NOx Emission}

Alteration in NOx emission for the different diesel - biodiesel - ethanol blends are shown in figure 10. When load increases, emission of NOX increases because of increase in internal temperature of cylinder. Biodiesel blends are lower NOx emission as compare to pure diesel fuel. This is because of higher viscosity and lower calorific value. Pure diesel has NOx emission of $3088.6075 \mathrm{ppm}$ and it is highest among the all tested fuel shown in figure 11. At full loading condition, corresponding values of MB20 and MBE20 are 2624.678 and 1987.423 ppm respectively. Almost for every case, on increasing loading conditions, NOx emission increases. More energy is released during combustion because increasing load requires more fuel.

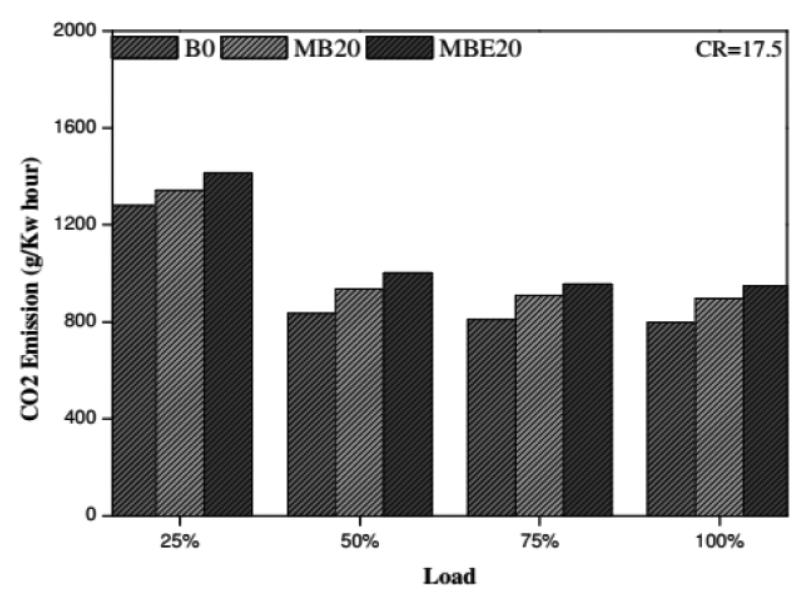

Figure 10. Variation of $\mathrm{CO} 2$ emission with engine load

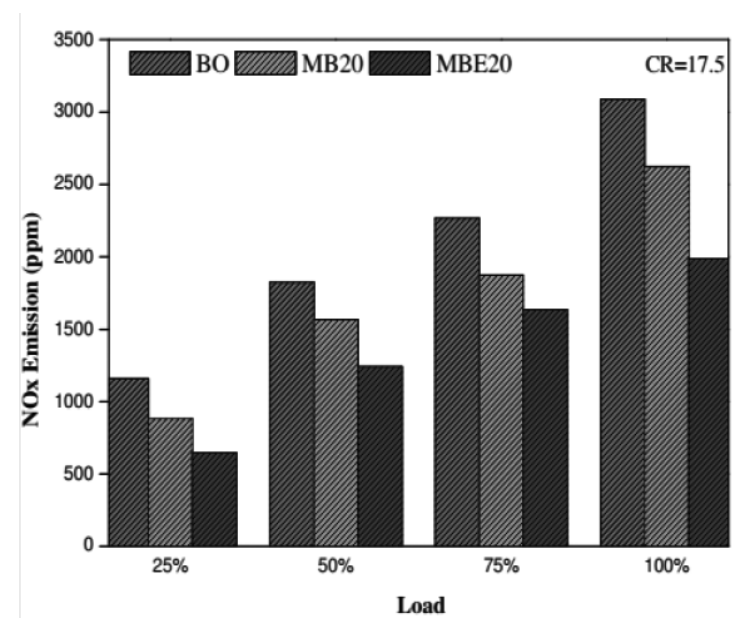

Figure 8. Variation of NOX with engine load

\section{CONCLUSION}

Following conclusions are drawn based on the performance, combustion and emission characteristics. Overall performance, combustion and emission characteristic of CI engine at different loading condition $(25 \%, 50 \%, 75 \%, 100 \%)$ will be effected by varying properties of diesel and its blend fuel. At full load and at CR 17.5 blends MB20, MBE20 has higher SFC of about $8.9 \%$ and $2.9 \%$ respectively than that of diesel fuel. For all tested fuel, with an increase in loading condition, we have a decreasing pattern of SFC and most optimum result is obtained in MBE20 blend. EGT is higher for blends than diesel fuel for all loading condition. BTE is higher for diesel fuel than biodiesel blends (MB20 andMBE20). Ignition delay is decreases when load increases and minimum ignition delay has MB20 and maximum ignition delay is in B0. MRPR is decrease by 3.06\% in MBE20 as compared to B0. By adding alcohols to biodiesel, NOx formation from biodiesel blend can be sorted, when $20 \%$ ethanol is mixed in biodiesel blend than NOx emission decreases by $35.6 \%$. Future prospective can be focused on implementation of different blends by varying blends of alcohols and further comparing to blend characteristics with diesel fuel. 


\section{REFERENCES}

Tamilselvan, P., Nallusamy, N., \& Rajkumar, S. 2017. A comprehensive review on performance, combustion and emission characteristics of biodiesel fuelled diesel engines. Renewable and Sustainable Energy Reviews. 79: 1134-1159.

Shrivastava, P., \& Verma, T. N. 2020. Effect of fuel injection pressure on the characteristics of CI engine fuelled with biodiesel from Roselle oil. Fuel: 265, 117005.

Acharya, N., Nanda, P., Panda, S., \& Acharya, S. 2017. Analysis of properties and estimation of optimum blending ratio of blended mahua biodiesel. Engineering Science and Technology, an International Journal. 20 (2): 511-517.

Gonzalez-Garcia, S., Moreira, M.T., \& Feijoo, G. 2010. Environmental performance of lignocellulosic bioethanol production from Alfalfa stems. Biofuels, Bioproducts and Biorefining. 4(2): 118-131.

Chaurasiya PK, Singh SK, Dwivedi R, Choudri RV.2019. Combustion and emission characteristics of diesel fuel blended with raw jatropha, soybean and waste cooking oils. Heliyon. 5(5):e01564.

Mofijur, M., Masjuki, H. H., Kalam, M.A., Atabani,A. E., Arbab, M. I., Cheng, S. F., \& Gouk, S. W. 2014. Properties and use of Moringa oleifera biodiesel and diesel fuel blends in a multi-cylinder diesel engine. Energy Conversion and Management. 82:169-176.

Rashed, M. M., Kalam, M. A., Masjuki, H. H., Mofijur, M., Rasul, M. G., \& Zulkifli, N. W. M. 2016. Performance and emission characteristics of a diesel engine fueled with palm, jatropha, and moringa oil methyl ester. Industrial crops and products. 79: 70-76.

Rajak, U., Nashine,P., Singh, T.S., \& Verma, T.N. 2018. Numerical investigation of performance, combustion and emission characteristics of various biofuels. Energy Conversion and Management. 156: 235-252.

Bencheikh, K., Atabani, A. E., Shobana,S., Mohammed, M. N., Uğuz, G., Arpa, O., \& Bokhari, A. 2019. Fuels properties, characterizations and engine and emission performance analyses of ternary waste cooking oil biodiesel-Diesel-Propanol blends. Sustainable Energy Technologies and Assessments. 35: 321-334.

Datta, A., \& Mandal, B. K. 2017. Engine performance, combustion and emission characteristics of a compression ignition engine operating on different biodiesel-alcohol blends. Energy. 125: 470-483.

How, H. G., Masjuki, H. H., Kalam, M. A., Teoh, Y. H., \& Chuah, H. G. 2018. Effect of Calophyllum Inophyllum biodiesel-diesel blends on combustion, performance, exhaust particulate matter and gaseous emissions in a multi-cylinder diesel engine. Fuel. 227: 154-164.

da Silva, J. P., Serra, T. M., Gossmann, M., Wolf, C. R., Meneghetti, M. R., \& Meneghetti, S. M. 2010. Moringa oleifera oil: studies of characterization and biodiesel production. Biomass and Bioenergy. 34(10): 1527-1530.

McAulay, K. J., Wu, T., Chen, S. K., Borman, G. L., Myers, P. S., \& Uyehara, O. A. 1966. Development and evaluation of the simulation of the compression-ignition engine. SAE Transactions, 560-593.

Rajak, U., \& Verma,T. N. 2018. Effect of emission from ethylic biodiesel of edible and non-edible vegetable oil, animal fats, waste oil and alcohol in CI engine. Energy Conversion and Management. 166, 704-718.

Li, X. K., Ji, W. J., Zhao, J., Wang, S. J., \& Au, C. T. 2005. Ammonia decomposition over Ru and Ni catalysts supported on fumed SiO2, MCM-41, and SBA-15. Journal of Catalysis. 236(2):181-189.

Lapuerta, M., Armas, O., \& Rodriguez-Fernandez, J. 2008. Effect of biodiesel fuels on diesel engine emissions. Progress in energy and combustion science. 34(2):198-223.

Rajak, U., Nashine, P., Singh, T. S., \& Verma, T. N. 2018. Numerical investigation of performance, combustion and emission characteristics of various biofuels. Energy Conversion and Management. 156: 235-252. 
Jaliliantabar, F., Ghobadian, B., Carlucci, A. P., Najafi, G., Ficarella, A., Strafella, L., De Domenico, S. 2018. Comparative evaluation of physical and chemical properties, emission and combustion characteristics of brassica, cardoon and coffee based biodiesels as fuel in a compression-ignition engine. Fuel. 222: 156-174.

Shrivastava, P., Verma, T. N., \& Pugazhendhi, A. 2019. An experimental evaluation of engine performance and emisssion characteristics of CI engine operated with Roselle and Karanja biodiesel. Fuel. 254: 115652.

Ozener, O., Yuksek, L., Ergenç, A. T., \& Ozkan, M. 2014. Effects of soybean biodiesel on a DI diesel engine performance, emission and combustion characteristics. Fuel. 115: 875-883.

Shrivastava, P., \& Verma, T. N. 2019. An experimental investigation into engine characteristics fueled with Lal ambari biodiesel and its blends. Thermal Science and Engineering Progress. 100356. 